\title{
Dominant Factors Affecting In Quality Of Life Menopause Women
}

\author{
Imarina Tarigan ${ }^{1}$ \\ Reproduction Health, Public Health Faculty \\ University of Sumatera Utara \\ Medan, Indonesia \\ imarinatarigan91@gmail.com
}

\author{
Sri Rahayu Sanusi ${ }^{2}$ \\ Population and Biostatistic, Public Health Faculty \\ Public Health Faculty, University of Sumatera \\ Utara \\ Medan, Indonesia \\ rahayusanusi01@gmail.com
}

\begin{abstract}
Menopause is a condition when physiological menstruation cycle concerning the human growing older. The increase in the number of growing old women will have its own problem with complaints about menopause. Although it does not cause death, it brings about uncomfortable condition and sometimes disturbs daily activities so that it can influence the life quality of menopause women. The research used observational method with cross sectional design. It was conducted at Kabanjahe Puskesmas, Karo Regency, from February until June, 2017. The population was 103 menopause women who regularly visited Kabanjahe Puskesmas, taken by using purposive sampling technique. The data were gathered by using questionnaires to get information about menopause syndrome, and quality life of menopause women. The result of univariate analysis showed that 71 respondents had good life quality. The result of bivariate analysis, using chi square test, showed that the factors which influenced life quality of menopause women were education, occupation, the duration of menopause, and menopause syndrome, but parity did not have any influence on the life quality of menopause women.The conclusion was that there was the correlation of education, occupation, duration of menopause, and menopause syndrome with the life quality of menopause women. The factor which had the most dominant influence was menopause syndrome. It is recommended that menopause clinic and health care board which is related to health care providers be established.
\end{abstract}

Keywords- Menopause; Quality of Life; Women Growing Old

\section{INTRODUCTION}

According to the Ministry of Health RI 2013, currently demographic in the world is undergoing a change, along with the increasing of health sector development, that is increase of Age of Life Expectancy (UHH) causing proportion of population aged $>60$ years also increase. Life expectancy and elderly (elderly) numbers are increasing, indeed reflecting improved health, will but this poses a challenge in the future as it raises various health and economic problems. It is estimated that the number of elderly population in Indonesia in 2020 will reach 28.8 million people or about $11 \%$ of the total population of
Indonesia. In the year 2021 the elderly in Indonesia is estimated to reach 30.1 million women which is the order number 4 in world. A woman will leave the reproductive age (Generally ranged between 15-44 years). This process will inevitably have an impact on the changing needs of reproductive health services. The median age of menopause, ie a period without menstruation, is 51.3 years and menopause can occur at 48-55 years of age [1].

The emergence of some diseases is often experienced by menopause women. From the medical point of view there are 2 most important changes that occur at the time of menopause, namely the increased possibility of heart disease and blood vessels, and loss of minerals and proteins in the bone (osteophorosis) [2].

Most of the myths or beliefs that developed in society about menopause are so believed that it leads women to experience negative perceptions during menopause. First women who experience automatic menopause predicated to old age. Second, the feeling that he is no longer needed and not appreciated, this will lower even stop his desire to perform the activity. He also will increasingly isolate and get out of social activities and community. Third, women experience menopause, loss of sexual attraction and decreased sexual activity. Fourth, the other myth is that the menopause period is the same as the shock of the soul, that is the appearance of the symptoms of fear, tension, sadness, irritability, and irritability [3].

Menopause is the cessation of ovulation caused by the absence of ovarian oocyte response (ovary) is characterized by decreased estrogen and progesterone hormone, this is a natural process for women. It said menopause is when the cycle menstruation has stopped for 1 year and usually occurs at the age of 48-50 years. Various complaints of menopause that arise in the form of short-term complaints (hotflushes) and long-term complaints are referred to as menopause syndrome. The estimated average age of menopause in Indonesia is 50-52 years, while the average age of premenopause is 40-48 years [4].

The World Health Organization-Quality of Life (WHOQOL) divides the quality of life in six domains: physical, psychological, level of freedom, social, environmental and spiritual relations, religion, which is then summarized into 
four domains. Physical health, psychological health, social relationship, environment [5].Increasing number of elderly women is certainly going to cause its own problems, especially coupled with the emergence of complaints in the menopause. Although not cause death, menopause can cause discomfort and disruption in daily work that can degrade the quality of life. Such conditions certainly require an appropriate handling to be ready to face menopause complaints, as well as anticipate cardiovascular disease, osteoporosis, and cancer.

Research on the factors that affect the quality of life women menopause is important and deserves special attention. Based on the above background, the researchers are interested to raise the issue in a study entitled The Factors Influence Quality Of Women Life Menopause In Kabanjahe Puskesmas, Karo Regency 2017.

\section{RESEARCH METHOD}

This study was an observational analytic study with cross sectional study design [6]. In this study the relationship of the variables tested were The Factors Influence Quality Of Women Life Menopause at Kabanjahe Puskesmas, Karo Regency 2017.

The location of this research is Kabanjahe Puskesmas, Karo Regency. The population in this study is all menopause women who regularly consult with health personel and follow the activities undertaken at Kabanjahe Health Center Karo Regency in 2017, such as fitness and PROLANIS (Chronic Disease Management Program). The population of 210 menopause women. Based on the formula calculation of the sample in obtaining the minimum sample size in this study were 103 menopause women. Sampling using purposive sampling technique using inclusion criteria of menopause women from age 45-55 years old, still have husband and live with family, able to read and write and willing to become informant, do not use hormone replacement therapy (TSH), not accompanied by disease, in a state of illness or under the supervision and treatment of a physician because of a particular disease, no history of uterine surgery (hysterectomy), or ovarian removal.

Primary data obtained directly from the source data by conducting interviews to respondents with a questionnaire guide. The primary data collected relating to the characteristics of the women of menopause include education level, parity, occupation and duration of menopause, which has been recorded in the questionnaire. Complaints about menopause were assessed using a questionnaire of menopause syndrome research instrument adopted from the Menopause Rating Scale (MRS). Family social support is measured using a questionnaire guide. Meanwhile, to assess the quality of life, data collection remains to be done with interviews with the World Health Organization's Quality Of Life-Bref questionnaire.

Univariate analysis is used to analyze the quality of life in each independent variable (independent variable) of menopause women, which includes menopause syndrome, education, parity, occupation, long menopause and family social support.

Bivariate analysis was conducted to determine the relationship of each independent variable with dependent variable using Chi-Square test at 95\% $(\alpha=0,05)$. Multivariate analysis by using logistic regression test to know the most dominant independent factor influence the dependent variable. Logistic Regression Test is done through several stages to get $p$ value $<0,05$ on every independent variable that influence to quality of life of menopause women.

\section{RESULT AND DISSCUSSION}

Based on the distribution of female characteristics of menopause at Kabanjahe Puskesmas, Karo Regency most of them with age category $\geq 50$ years counted 77 people $(74,8 \%)$, most in education with high category (Senior High School, University) as many as 75 people $(72,8 \%)$.

Women who have more than 2 children as many as 86 people $(83.5 \%)$, most menopause mothers do not work as many as 69 people $(67.0 \%)$, most menopause women have menopause less than 2 years as many as 56 people (54.4\%).

TABLE 1 FREQUENCY DISTRIBUTION OF FEMALE CHARACTERISTICS OF MENOPAUSE

\begin{tabular}{|c|c|c|c|}
\hline \multirow[t]{2}{*}{ No } & \multirow[t]{2}{*}{ Characteristics } & \multicolumn{2}{|c|}{ Amount/Total } \\
\hline & & f & $\%$ \\
\hline 1 & $\begin{array}{l}\operatorname{Age}(\text { th }) \\
<50 \\
\geq 50\end{array}$ & $\begin{array}{l}26 \\
77\end{array}$ & $\begin{array}{l}25,2 \\
74,8\end{array}$ \\
\hline 2 & $\begin{array}{l}\text { Education } \\
\text { SD \& SMP } \\
\text { SMA } \\
\text { University }\end{array}$ & $\begin{array}{l}28 \\
48 \\
27\end{array}$ & $\begin{array}{l}27,2 \\
46,6 \\
26,2\end{array}$ \\
\hline 3 & $\begin{array}{l}\text { Parity } \\
<2 \\
\geq 2\end{array}$ & $\begin{array}{l}17 \\
86\end{array}$ & $\begin{array}{l}16,5 \\
83,5\end{array}$ \\
\hline 4 & $\begin{array}{l}\text { Occupution } \\
\text { Work } \\
\text { Jobless }\end{array}$ & $\begin{array}{l}34 \\
69\end{array}$ & $\begin{array}{l}33,0 \\
67,0\end{array}$ \\
\hline 5 & $\begin{array}{l}\text { Duration of Menopause } \\
\text { (th) } \\
<2 \\
\geq 2\end{array}$ & $\begin{array}{l}56 \\
47\end{array}$ & $\begin{array}{l}54,4 \\
45,6\end{array}$ \\
\hline
\end{tabular}

The end result of multivariate analysis of logistic regression because the old variable of menopause, family social support, and menopause syndrome have $\mathrm{p}$ value $<0,05$ means that the variables are not released, thus the three variables have an influence on the quality of life of women menopause. Overall the most influential variable on the quality of life of women menopause is menopause syndrome with $\operatorname{Exp}(B)=64,197$ indicating the largest number.

Based on the results of the analysis, the regression equation can be written as follows: 


$$
\begin{aligned}
& p=\frac{1}{1+e^{-y}} \\
& p=\frac{1}{1+e^{-((-8,582+4,162+3,112)+(-1,847))}} \\
& p=\frac{1}{1+1,261.858^{-(-3,155)}} \\
& p=0,67564 \times 100 \% \\
& p=67,6 \%
\end{aligned}
$$

From the above equation is known that in menopause women who experience menopause less than 2 years, abnormal menopause syndrome and adequate family support has a $67.6 \%$ chance to experience a poor quality of life.

\section{Quality Life of Women's Menopause}

The results showed that menopause women in Kabanjahe Health Center mostly with good life quality category that is $71(68,9 \%)$ menopause women. Overall quality of life of menopause women at Kabanjahe Puskesmas average to say mediocre in running their lifes, especially health and feel satisfied with the environment and social relationships.

The same with research conducted by[7], states that high quality of life can be seen from menopausal women who are able to recognize themselves (aware of the shortcomings and advantages possessed), able to adapt to the conditions of menopause experienced, can feel the suffering of others, get affection, be optimistic, and able to develop empathy attitude.

\section{The Quality Life of Women's Menopause in Education}

The result of univariate analysis showed that women menopause in Kabanjahe Puskesmas mostly with higher education category were 75 people $(72.8 \%)$. The results showed that there was a significant correlation between education and quality of life of menopause women, the results of this study were in line with the results of research conducted by [8], at Sukahaji Public Health Center of Majalengka Regency and [9], research results at Puskesmas Sumbersari Kabupaten Jember significant between education and quality of life of menopause women.

Based on the results of the study showed that most menopause women with a good quality of life, the quality of life is subjective tend to be better in menopause women who are highly educated. In line with the study of [10], it is said that the higher the education is likely to get social support from people around it so as to have a good quality of life menopause.

In line with the theory put forward by [11], it is said that high education is considered necessary for women, because of the high level of education so they can improve their standard of life, make decisions that concern the problem of their own health. The higher a woman's education will be easy to accept new things and easily adjust to new problems. Education will affect one's knowledge, the higher the level of education the easier it will be for the person to receive the information [12].

The result of multivariate analysis with logistic regression showed that education did not gave influence to the quality of life of menopause women.

\section{Job of Women Menopause in Quality Life}

The univariate analysis showed that most respondents in the category did not work for meopause women at Kabanjahe Health Center that was 69 people $(67,0 \%)$. The results showed that there was a significant relationship between the work and the quality life of women menopause.

The result of this research is in line with research done by [10], in Karang Jeruk Village, Jatirejo Sub-district, Mojokerto Regency, that there is a significant correlation between work and quality of life of menopause women. The work determines the income of a person who influences the availability of a facility necessary for certain activities such as information media to increase knowledge. In line with the opinion of [13], which states that low income is related to the quality of life of menopause women. This socioeconomic situation will affect physical factors, health and education on a person, if these factors are good enough then it will be able to reduce physiological and psychological burden.

From the results of most research menopause women do not work and have no income but menopause women who do not have income does not mean they have no money at all. Although these menopause women are unemployed and have no income, they still earn money from their husbands, children or relatives so that at least they can still meet their needs. The results of multivariate analysis with logistic regression showed that the work did not affect the quality of life of menopause women.

\section{Menopause Duration in Quality Life of Women's Menopause}

Univariate analysis of the study showed that most menopause women had menopause $>2$ years as many as 56 people $(54.4 \%)$. The results of bivariate analysis showed that there was a significant relationship between the length of menopause and the quality of life of menopause women. The results of this study are in line with research conducted by [10], in Karang Jeruk Village, Jatirejo Sub-district, Mojokerto Regency, that there is a significant relationship between menopause and the quality life of menopause women. Long experience of this menopause affects the psychological adaptation to changes that occur in menopause that impact on the quality life of menopause. The longer the menopause is the quality of life is good because menopause women have been able to adapt to changes that occur during menopause.

According [11], long experience of this menopause affect the psychological adaptation to changes that occur in 
menopause that impact on the quality of life of menopause women. The results of multivariate analysis with logistic regression showed that the length of menopause affects the quality life of menopause women. The longer the menopause is the quality of life is good because menopause women have been able to adapt to changes in menopause. Has achieved a new hormonal balance, so it is able to get used to vegetative disorders and psychological disorders during menopause.

Women menopause with long-term menopause less than 2 years of age mostly have poor quality of life and menopause women with longer menopause more than 2 years of age mostly have good quality of life.

\section{Menopause Syndrom in Quality Life of Women's Menopause}

The result of univariate analysis showed that most menopause women had menopause syndrome in the mild to moderate category of 88 people $(85,4 \%)$, and heavy to very severe category were 15 people $(14,6 \%)$. The result of bivariate analysis shows that there is a significant correlation between menopause syndrome and the quality life of menopause women. The results of this study are in line with research conducted by [8], at Sukahaji Public Health Center of Majalengka Regency and research conducted by [14], menopause syndrome from the physiological and psychological aspects with the quality of life of menopuase women.

According to [13], the decline in ovarian function (ovum) causes hormones, especially estrogen and progesterone greatly reduced in our body. Lack of this estrogen hormone causes physical and psychological complaints that will affect the quality life of women. Quality of life is an individual perception of their functioning in the sphere of life. If this is not addressed properly will make yourself concerned feel uncomfortable with the condition that it is already his nature as a woman. During the menopause phase there will be some symptoms accompanied by grievances that often make women become anxious and feel depressed due to significant changes to the hormonal system so as to create discomfort. Symptoms and symptoms that accompany the menopausal phase If the menopause is linked to the dimensions of quality of life that have been released by WHO, then clearly the quality of life of women who menopause decreased.

The result of multivariate analysis with logistic regression showed that menopause syndrome had an effect on the quality life of menopause women. Decreased menopause symptoms show a great improvement in the quality of life compared to the increase in menopause symptoms, menopause women experience symptoms at the time of menopause and in some will survive for several years so that quality life will be disrupted.

\section{Limitations of Results}

1. The variables studied are not too much due to limited time and ability of researchers in conducting research so that the results of analysis at other times will be different.

2. Giving questionnaires is not followed by in-depth interviews so that research is less profound because it uses a questionnaire that is closed.

\section{CONCLUSION}

Based on the results of research and discussion can be drawn some conclusions that is, there is a relationship between education with the quality life of menopause women in Kabanjahe Puskesmas, Karo District, with RP = 2.363. There is between relationship with the quality life of menopause women in Kabanjahe Puskesmas, with RP = 1.573. There is a relationship between menopause age and quality life of menopause women at Kabanjahe Puskesmas, Karo District, with RP $=5,875$. There is an association between menopause syndrome and the quality life of menopause women at Kabanjahe Puskesmas, with RP = 11.932. Overall, the most influential variable on the quality life of menopause women is variable Menopause syndrome with the value $\operatorname{Exp}(B)=56,035$ shows the largest number. There is no parity relationship with the quality life of menopause women at Kabanjahe Puskesmas, Karo.

\section{V.RECOMMENDATION}

Based on the conclusion of the study, it can be given advice which is to improve the quality life of menopause women providing information about menopause and also diseases that usually occurs in postmenopause women, is very important for socialization and in-depth approach to menopause women and families. This can be done by the Puskesmas that can work together for example, posyandu elderly, and PKK. Puskesmas should approach and train village midwives, cadres and women to help convey correct information about menopause to the community.

\section{REFERENCES}

[1] Kusmiran, E., 2011, Kesehatan Reproduksi Remaja dan Wanita, Jakarta : Salemba Medika.

[2] Mubarak, I. Q., 2012. Ilmu Kesehatan Masyarakat : Konsep dan aplikasi dalam kebidanan, Jakarta : Salemba Medika.

[3] Mulyani, N, 2015. Menopause Akhir siklus Mensturasi Pada Wanita di Usia Pertengahan, Yogyakarta : Salemba Medika.

[4] Proverawati, A, dan Sulistyawati, E. 2016. Menopause dan Sindrom Premenopause, Yogyakarta : Nuha Medika.

[5] WHOQOL-BREF, 2014.

[6] Notoatmodjo, S., 2012. Promosi Kesehatan Dan Prilaku Kesehatan, Cetakan Pertama, Jakarta: Rineka Cipta.

[7] Larasati, T., 2009, Kualitas Hidup pada Wanita yang Sudah Memasuki Masa Menopause. Fakultas Psikologi, Universitas Gunadarma.

[8] Astari, R, Tarawan, V, dan Sekarwana, N., 2014. Hubungan Anatara Sindrom Menopause Dengan Kualitas Hidup Perempuan Menopause Di Puskesmas Sukahaji Kabupaten Majalengka, : Universitas Padjadjaran Bandung Indonesia. Bul. Penelit. Kesehatan, Vol. 42, No. 3, September 2014: 171-184.

[9] Putri, D, Wati, D, dan Ariyanto, Y, 2014. Kualitas Hidup Wanita Menopause : Epidemiologi dan Biostatitiska Kependudukan, Fakultas 
Kesehatan Masyarakat, Universitas Jember.e-Jurnal Pustaka Kesehatan, vol 2 (no.1) Januari 2014.

[10] Syalfina, A, 2017. Body mass index (BMI) dan Lama Menopause Berpengaruh Terhadap Kualitas Hidup Menopause di desa karang jeruk kecamatan jatirejo kabupaten mojokerto, Poltekkes Majapahit, vol 9 (no. 1) Februari 2017.

[11] Widyastuti, Y, Rahmawati, A, dan Purnamaningrum, Y, 2010. Kesehatan Reproduksi, Yogyakarta : Fitramaya.

[12]Notoatmodjo, S., 2010. Metodologi Penelitian Kesehatan, Jakarta: Rineka Cipta.

[13]Kargenti, A, 2013, Kualitas Hidup Perempuan Menopause : UIN Suska Riau.

[14]Trisetiyaningsih, Y, 2016. Hubungan Antara Gejala Menopause dengan Kualitas Hidup Perempuan Klimakterium. Jurnal Kesehatan Samodra Ilmu Vol. 07. No. 01, Januari 2016. 